\title{
Gandhi puts India's claim to USA
}

New science

\section{link agreed \\ but no money}

\section{Washington}

Indian Prime Minister Mrs Indira Gandhi made her first visit to Washington in 11 years last week, during which she and President Ronald Reagan announced not only a settlement of the long-standing dispute over nuclear fuels for the Indian nuclear reactors at Tarapur but also a new high-level agreement on cooperation in science and technology.

Like the agreements on science that Washington signed with Moscow and later with Peking in the early 1970 s as a prelude to improved relations, the science accord could signal a new period of stable relations between Washington and New Delhi, which have been troubled for some years (see opposite).

In a day and a half of meetings with the President, members of Congress, the press and scientists, Mrs Gandhi made it clear that India does not consider itself a supplicant for US aid monies or hand-me-down technology from the United States. In a talk to the American Association for the Advancement of Science, she stressed India's strong indigenous high-science traditions, which have included worldclass contributions in many basic fields.

"It is an inherent obligation of a great country such as India, with its traditions of scholarship and original thinking and its great cultural heritage, to participate fully in the march of science", said Mrs Gandhi, quoting from the latest resolution on national science policy.

On the other hand, India most needs science and technology to serve development down to the village level as with the "fitting of tyres on bullock carts and the use of biogas plants", she said.

The new accord establishes a committee to be chaired jointly by Dr George A. Keyworth, the President's science adviser, and Professor M.G.K. Menon, chairman of the Indian Science Advisory Council. Other members have still to be chosen. The committee should produce suggestions for collaborative work by early next year, according to the White House, But the new group, while enjoying prestige, has not had any money allocated to it and it is not clear how any programmes it suggests will be carried out or funded.

Nyle C. Brady, senior assistant administrator of the US Agency for International Development, who will help to select the members of the committee, says that some projects could be funded by reshuffling the existing $\$ 80$ million in foreign aid that his

agency gives to India each year. He estimated that $10-20$ per cent of the money now goes on projects based on science and technology items. (Mrs Gandhi also tried to persuade the President of the importance of concessional financing to India for general development, but her arguments are said to have fallen on deaf ears.)

Likely areas of collaboration suggested by Mrs Gandhi and US officials include:

- Biomedical research to control leprosy, tuberculosis and waterborne diseases. India claims recently to have made advances in the control of leprosy, while US investigators are the source of its only natural host for experimental infection, the nine-banded armadillo.

- Nutritional blindness associated with severe vitamin A deficiency, a leading cause of blindness in many developing nations. Related work is already under way

\section{France to supply Tarapur fuels}

Washington

A major problem in US-Indian relations was removed last week when President Ronald Reagan and Prime Minister Indira Gandhi announced that they had resolved a long-standing dispute over whether the United States should continue to provide low-enriched uranium to Indian reactors at Tarapur, outside Bombay.

The two heads of state announced that the reactors would be able to keep operating because fuel would be provided by a third party, France. This circumvents a 1978 US law that appears to supersede the 1963 agreement and effectively bars US shipments to Tarapur. In return, India will continue to observe safeguards operated by the International Atomic Energy Agency.

Under the 1963 agreement, the United States became the exclusive supplier of low-enriched uranium to Tarapur. In return, India promised to observe bilateral safeguards.

But in 1978, Congress passed the nuclear anti-proliferation act which prohibited US export of nuclear fuels to any country that had not signed the 1968 Non-Proliferation Treaty. India has deliberately remained outside the treaty, so the act seemed to prevent continued shipments to Tarapur.

Under pressure from the Indian government, President Carter in 1980 used a provision in the 1978 act to authorize shipment of 38 tonnes of enriched uranium to Tarapur anyway. As recently as April 1981, the Reagan Administration was reported to be ready to cancel the 1963 agreement, and India was reported to be threatening to stop observing safeguards at Tarapur.

Under the new agreement, however, both the 1963 agreement and the 1978 act are upheld. The United States will not supply fuel to Tarapur - instead, the French will do so. But there are some in the United States, and US-Indian collaboration is taking place at the National Institute of Nutrition in Hyderabad.

- Birth control, especially development of possible vaccines as anti-fertility measures. - Agriculture and biomass. India has achieved self-sufficiency in grain production, a remarkable achievement for a nation of 700 million people. But, as Mrs Gandhi told reporters in Washington, most modern grain production increases consumption of energy. Energy conservation and cheap energy production are important priorities for the achivement of future increases in food production and overall standards of nutrition. The US Department of Agriculture and the landgrant colleges already contribute to this work.

India is especially interested in the possi-

sticking points, such as India's continued insistence that, under the 1963 agreement, it does not need US permission to reprocess spent fuel from Tarapur. It is estimated that there are 200 tonnes of fuel at Tarapur, 100 tonnes in the form of spent fuel and another 100 tonnes in the reactors. If all this were reprocessed into weapons grade material, it could be enough for 100 nuclear devices.

Two congressional watchdogs of nuclear proliferation, Representative Jonathan Bingham (Democrat, New York) and Senator John Glenn (Democrat, Ohio), say they are content with the Reagan-Gandhi deal.

Deborah Shapley

\section{France's decision}

In France, the decision to supply the enriched uranium has been taken at the political level; commercial questions such as price have yet to be decided.

Moreover, some political problems may still remain. For the enriched fuel would be produced by the Eurodif plant at Tricastin in the Rhône valley and Eurodif is not French but an international consortium of France, Italy, Spain, Belgium and Iran. Through a surviving Franco-Iranian company, Sofidif, Iran still owns 10 per cent of in Eurodif.

In principle Cogema, the French nuclear fuel company which owns 51 per cent of Eurodif, could buy the enriched uranium from Eurodif and resell it to India; or Eurodif itself could make the deal. Both arrangements might be expected to require the agreement of the other Eurodif partners. No decision on either arrangement has yet been taken, say French sources.

Robert Walgate 


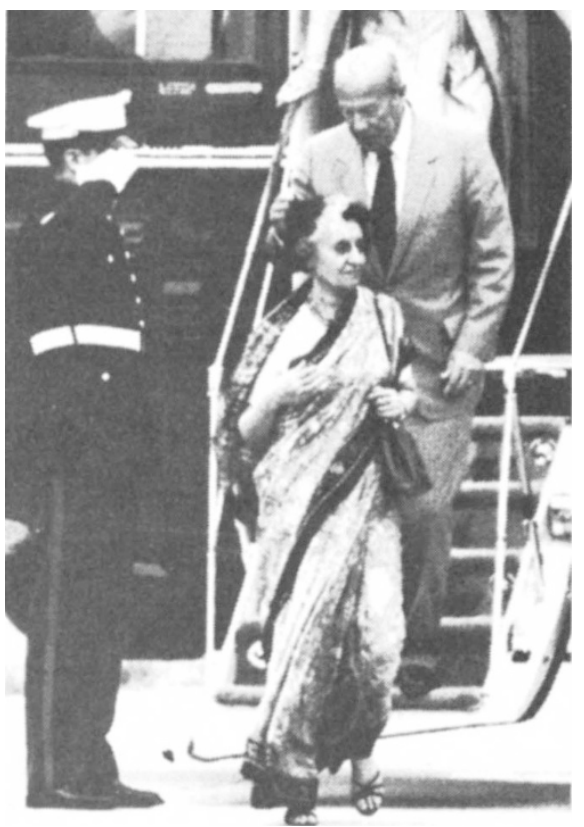

Wide-World Photo

Secretary of State George Schultz follows Mrs Gandhi's lead.

bilities of genetic engineering for the improvement of crop yields and to produce quick-growing trees to provide fodder and firewood for rural populations. Biotechnology, some Indians say, is an area where high science and the needs of development meet. Last January, Mrs Gandhi announced the creation of a National Biotechnology Board, of which Dr M.S. Swaminathan will be chairman.

- Energy, minerals and materials. Indians are already being trained in the use of the Landsat satellite for mineral surveys, and collaboration exists in the field of earthquake engineering.

The White House explained that the new committee should overcome some of the problems afflicting the subcommission on science and technology formed under the Joint Commission on Economic, Commercial, Scientific, Technological, Educational and Cultural Cooperation. The commission was created in 1974 in an earlier effort at US-Indian detente, in spite of US unhappiness with India's nuclear test a few months earlier.

The science subcommission apparently did not include sufficiently high-ranking people and so was not influential enough with each country's bureaucracy to get major projects started. The new committee, under the joint chairmanship of Dr Keyworth and Dr Menon, should not have such difficulties.

In an oblique reference to the many meetings of developing countries, including one held in India last March, Mrs Gandhi noted that bilateral arrangements were the most effective path for development. "Global conferences end with inspiring and laudable statements. But their commitments are seldom honoured" she said.

Deborah Shapley

\section{Electronics industries}

\section{French on march}

The French government last week declared war on world electronics* markets with a FF140,000 million ( $\$ 20,000$ million) three to five-year investment programme in the French electronics industry. After nuclear power (France now has the largest and fastest-growing nuclear programme in the world) and space (where the Ariane launcher is now competing effectively with the space shuttle) comes electronics, now clearly marked out as the technological programme of the new socialist France.

The battle will begin in the United States. M. Abel Farnoux, principal architect of the French programme, is expected to move to an office in New York in September and one of his partners, M. Girard Compain, is to set up shop in California. Altogether, some ten French electronics policy-makers are to move to the United States this year.

Their objective will be, in part, to learn, but the real French goal is the American market. France would seek both to establish French companies in the United States and to set up cooperation agreements. But so far the French government has given no details of Farnoux's new role. The decision last week was to adopt the main lines of Farnoux's recent report on the industry (see Nature 27 May p.257) and to announce an investment figure.

The most difficult domestic question has been avoided - how to reorganize the French electronics industry at home. The problem is that some of the major com-

"The word "electronics" is used to include everything from materials production to television sets, communications and computers. The French see their 10 main competitors in th Siemens, Matshushita, Hitachi, GTE and Toshiba.

\section{Balancing the francs}

The French Ministry of Research and Industry is doing its best to juggle with a tight budget for 1983 - and to make it seem not too different from the 4-year averages recently advertised in the research law passed by the National Assembly (17.8 per cent a year in real money, and 4.5 per cent a year in jobs). The budget will not be announced before September: it seems likely that the cash target will be achieved, but not the jobs.

This represents a political decision that in the short run it is more important to get on with research, and to re-equip laboratories, than to create new posts. The figures under discussion would give something like a 2-3 per cent increase in posts (up to 600 new positions) at the Centre National de la Recherche Scientifique, which is responsible for the bulk of basic science in France; 6 per cent (230 posts) at INSERM, which pursues medical research; and 3 per cent (200) at INRA (agriculture). The total civil research budget would rise the full 17.8 panies - such as Thomson CSF, which produces military equipment, telephone exchanges, minicomputers, microchips, television sets and hi-fi equipment - have clear ideas of their own about their competence and company strategies, and have resented the government interference implied by their recent nationalization.

Thus Thomson was recently attempting to put its own foot in the American market through cooperation in the minicomputer market with an American company, but the French government stepped in and despite Farnoux's attachment to the United States - insisted that Thomson link up instead with the mostly French computer company CII-Honeywell-Bull. This has riled the Thomson management, not least because the French company had earlier undermined Thomson's own minicomputer operation with the introduction of a Honeywell system (the "Level 6") despite an agreement not to do so.

Thus internal strife may make the French electronics adventure less of a threat than it might otherwise be. Meanwhile, money will certainly pour into the industry, and that alone may give it a competitive edge. It seems likely that the government will provide FF10,000 million in support of component manufacture (basically chips); FF7,000 million in consumer electronics; FF15,000 million in computers and office automation; FF 15,000 million in the space industries; FF3,200 million in industrial automation; FF2,000 million in scientific instrument manufacture; FF3,000 million in medical electronics; and FF4,500 million in software production. On top of this, the industry itself is expected to invest some FF90,000 million over the planning period (to 1986), a rate not far from its present figure.

Robert Walgate

per cent to around FF32,000 million ( $£ 2,700$ million).

All this takes place against a total government budget constrained to grow only 4.1 per cent in real terms next year, and a number of items written into the 1983 science budget that were not envisaged in the law, including FF1,000 million to help equip the science museum at La Villette, north of Paris, and FF500 million to support the computer firm CIIHoneywell-Bull.

Even so, the government is assuming only an 8 per cent inflation rate next year. Current inflation is in double figures. And in spite of the apparently large increases announced for 1982 , the real increases in laboratory budgets have been eaten into by inflation and the weakness of the franc against the dollar. For example, despite a nominal 30 per cent increase, the budget of one director of a molecular biology laboratory in France this year was only 5 per cent up in buying power. But he was not complaining: "That's probably much better than my foreign colleagues". Robert Walgate 